\title{
Villous Adenoma Arising in the Urethra of a Female with Bladder Augmentation History: A Case Report and Review of the Literature
}

\author{
Hale DEMiR ${ }^{1}$ (D) Selçuk CiN² (D), Sinharib CiTGEZ3 ${ }^{\mathbb{D}}$, Nesrin UYGUN ${ }^{4}$ (D) \\ Department of Pathology, 'Amasya University, School of Medicine, AMASYA, TURKEY, ${ }^{2}$ Bagcilar Training and Research Hospital, ISTANBUL, TURKEY \\ Department of ${ }^{3}$ rology and ${ }^{4}$ Pathology, Istanbul University-Cerrahpasa, Cerrahpasa School of Medicine, ISTANBUL, TURKEY
}

\begin{abstract}
Villous adenomas (VAs) in the female urethra are rare with only seven cases in the English literature to our knowledge. In patients with bladder augmentation cystoplasty, the neoplasia development risk increases and most of these develop in the neobladder or anastomosis line. Only two cases of VA developing from the native bladder mucosa have been reported. Physical examination of a 76-year-old female who had a history of augmentation cystoplasty revealed a caruncula-like structure protruding from the urethral meatus. The urinary USG showed that the lesion had no relation with the bladder. The lesion was excised. Microscopically, it consisted of villous structures covered with pseudostratified intestinal type epithelium. Low-grade dysplasia was present in the epithelium but high-grade dysplasia or in-situ/invasive carcinoma was not observed. Immunohistochemical study showed positivity for CK7, CK20, EMA, CEA and CDX2. The case was reported as VA of the urethra. We presented the first VA case arising in the urethra of a female patient with intestinal bladder augmentation. Excision is curative for pure VAs. Transformation to carcinoma or recurrence has not been reported. However, in one third of the cases, a malignant tumor may accompany the lesion. Therefore, all excision material should be examined carefully. Routine endoscopic follow-up should be performed in cases with bladder augmentation.
\end{abstract}

Keywords: Villous adenoma, Urethra, Urinary tract, Bladder augmentation

\section{INTRODUCTION}

Villous adenomas (VAs) of the urinary tract are rare with only two case series and around 20 scattered case reports in the literature (1-3). Histologically and immunohistochemically, these tumors are similar to VAs of the gastrointestinal system $(1,3)$. They are frequently seen in elderly patients with a predilection for the urachus, dome and trigone of the bladder $(1,4)$. Male predominance has been reported $(1,2,5)$. VAs of the female urethra are very rare with only seven cases in the English literature to our knowledge (Table I) (1, 6-11).

In the etiology, it has been considered that urinary tract VAs might develop from the cloacal remnants from which the distal colorectum, bladder and urethra originate during embryogenesis. On the other hand, they may also be a product of the chronic irritation-metaplasia-dysplasiacarcinoma sequence (3).

In patients with bladder augmentation cystoplasty, it is reported that the risk of carcinoma development increases (4). Most of these carcinomas develop in the neobladder or anastomosis line. Only 2 cases of VA that developed from the native bladder mucosa have been reported (Table II) (4,

(Turk Patoloji Derg 2021, 37:161-166)

Received : 19.06.2020 Accepted : 14.07.2020
12). It is thought that the development of VA in patients with bladder augmentation supports the second theory.

We present the first VA case arising in the urethra of a female patient with intestinal bladder augmentation.

\section{CASE REPORT}

A 76-year-old female patient was hospitalized because of high urea and creatinine levels. She had a history of intestinal augmentation cystoplasty due to small capacity hypersensitive bladder 30 years ago. The ileal segment was augmented to the bladder dome. The bladder trigone and urethra were not interfered with. Clean intermittent catheterization (CIC) was recommended to the patient after the first augmentation, but she did not do it regularly.

She was diagnosed as postrenal acute renal failure. A catheter was inserted and the urea-creatinine levels began to decrease. She had bilateral hydroureteronephrosis. After 4 months, physical examination revealed a carunculalike structure protruding from the urethral meatus. The urinary USG revealed that there was no relation with the bladder. The urethral lesion was excised, and then the bilateral hydroureteronephrosis regressed. CIC was not 
Table I: Summary of our case and literature review of cases of villous adenoma arising in the female urethra.

\begin{tabular}{|c|c|c|c|c|c|c|c|}
\hline Reference & $\begin{array}{c}\text { Age } \\
\text { (years) }\end{array}$ & Symptoms & $\begin{array}{l}\text { Size } \\
(\mathrm{mm})\end{array}$ & $\begin{array}{l}\text { Coexisting } \\
\text { malignancy }\end{array}$ & Treatment & $\begin{array}{c}\text { Follow-up } \\
\text { (months) }\end{array}$ & Outcome \\
\hline $\begin{array}{l}\text { Powell et al. } \\
\text { (8) }\end{array}$ & 59 & $\begin{array}{c}\text { Polypoid lesion } \\
\text { protruding from } \\
\text { the urethral meatus, } \\
\text { hematuria }\end{array}$ & $8 \times 8$ & Adenocarcinoma & $\begin{array}{l}\text { Transurethral } \\
\text { excision }\end{array}$ & 15 & Alive \\
\hline $\begin{array}{l}\text { Howells and } \\
\text { Baylis(10) }\end{array}$ & 70 & $\begin{array}{c}\text { Vaginal discharge, } \\
\text { dysuria }\end{array}$ & $30 \times 20 \times 15$ & Absent & $\begin{array}{l}\text { Surgical } \\
\text { resection }\end{array}$ & 22 & Alive \\
\hline $\begin{array}{l}\text { Raju et al. } \\
\text { (9) }\end{array}$ & 58 & $\begin{array}{l}\text { Asymptomatic mass } \\
\text { increasing in size }\end{array}$ & 10 & Absent & Tumor excision & 72 & $\begin{array}{l}\text { Alive } \\
\text { with no } \\
\text { recurrence }\end{array}$ \\
\hline $\begin{array}{l}\text { Morgan et } \\
\text { al. (11) }\end{array}$ & 87 & $\begin{array}{c}\text { Asymptomatic } \\
\text { polypoid urethral mass }\end{array}$ & $20 \times 15 \times 10$ & Absent & Tumor excision & 24 & Dead $^{*}$ \\
\hline $\begin{array}{l}\text { Cheng et al. } \\
\text { (1) }\end{array}$ & 81 & Hematuria & Unknown & Absent & Unknown & Unknown & Unknown \\
\hline $\begin{array}{l}\text { Noel et al. } \\
\text { (7) }\end{array}$ & 49 & $\begin{array}{l}\text { Painful paraurethral } \\
\text { tumor increasing in } \\
\text { size, hematuria }\end{array}$ & $30 \times 28 \times 25$ & $\begin{array}{c}\text { Adenosquamous } \\
\text { carcinoma }\end{array}$ & $\begin{array}{l}\text { Wide tumor } \\
\text { excision }\end{array}$ & 16 & $\begin{array}{l}\text { Alive } \\
\text { with no } \\
\text { recurrence }\end{array}$ \\
\hline $\begin{array}{l}\text { Qin et al. } \\
\text { (6) }\end{array}$ & 63 & $\begin{array}{c}\text { A mass in the urethral } \\
\text { orifice increasing in } \\
\text { size }\end{array}$ & $40 \times 30$ & $\begin{array}{c}\text { Well } \\
\text { differentiated } \\
\text { adenocarcinoma }\end{array}$ & $\begin{array}{l}\text { Whole urethra } \\
\text { and part of } \\
\text { the bladder } \\
\text { resection }\end{array}$ & 11 & $\begin{array}{l}\text { Alive } \\
\text { with no } \\
\text { recurrence }\end{array}$ \\
\hline Present case & 76 & $\begin{array}{l}\text { Polypoid lesion } \\
\text { protruding from the } \\
\text { urethral meatus }\end{array}$ & $45 \times 20 \times 15$ & Absent & Tumor excision & 28 & $\begin{array}{l}\text { Alive } \\
\text { with no } \\
\text { recurrence }\end{array}$ \\
\hline
\end{tabular}

* The patient died 2 years later of a cerebral infarction.

recommended for postoperative follow-up, as the patient had no residual urine.

The macroscopic examination of the lesion revealed a cream-white colored, fragile and polypoid mass, $4.5 \times 2 \times 1.5$ $\mathrm{cm}$ in size. Its base was $1.5 \times 1 \mathrm{~cm}$ in size, hemorrhagic and brown colored. On the cut sections, it was composed of thin papillary structures adhering to a fibrous core.

On microscopic examination, the tumor consisted of villous structures covered with pseudostratified intestinal type epithelium. Low-grade dysplasia and occasional squamous metaplasia areas were present in the epithelium (Figure 1A-D). All material was investigated and high-grade dysplasia or in-situ / invasive carcinoma was not observed. Immunohistochemical study showed positivity for CK7, CK20, EMA, CEA and CDX2 (Figure 2A-E).

The case was reported as VA of the urethra. The adenomatous epithelium was adjacent to the surgical margin. However, there was no surgical recurrence in the 28-month followup. During follow-up, there was no renal dysfunction or hydronephrosis. The patient stated that she was more comfortable after the operation and could urinate.

\section{DISCUSSION}

Urinary tract VAs are benign glandular lesions which are histologically and immunohistochemically similar to VAs of the gastrointestinal tract $(1,3,13)$. They are mostly seen in patients aged 33 to 79 years with a mean age of 57 years (14). Male predominance has been reported ( 1 , $2,5)$. Patients usually present with hematuria, irritation symptoms and rarely mucusuria $(1,15)$. Back or flank pain, fever, abdominal discomfort and weight loss can be seen in patients with pelvic VAs (16). There is no specific diagnostic finding on the USG, CT, MRI or cystoscopy $(17,18)$.

In the past, various terms have been used to describe these tumors as villous adenoma, tubulovillous adenoma, villous metaplasia of the intestinal type with dysplasia, and enteric adenoma. However, using the villous tumor or villous polyp terms must be avoided because they can lead to confusion with prostatic-type polyps (19). 
Table II: Villous adenoma arising from the urinary mucosa in the patients with a history of augmentation.

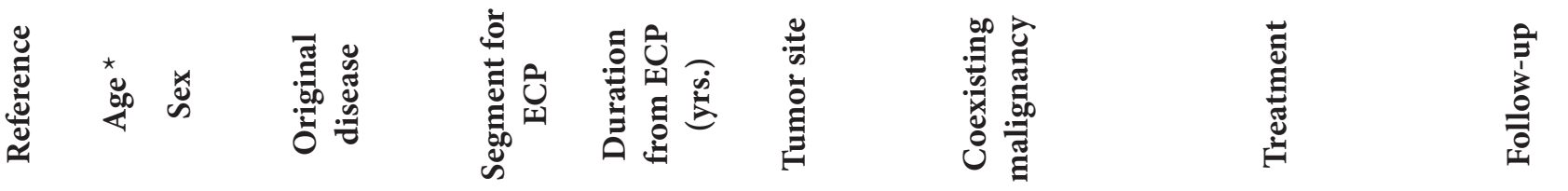

\begin{tabular}{|c|c|c|c|c|c|c|c|c|c|}
\hline $\begin{array}{l}\text { Lin et } \\
\text { al. (12) }\end{array}$ & 25 & $\mathrm{~F}$ & $\begin{array}{l}\text { Small } \\
\text { capacity- } \\
\text { neurogenic } \\
\text { bladder }\end{array}$ & Stomach & 16 & $\begin{array}{c}\text { Native } \\
\text { bladder }\end{array}$ & Adenocarcinoma & $\begin{array}{l}\text { Resection of } \\
\text { recontracted } \\
\text { stomach part and } \\
\text { wedge excision of } \\
\text { tumor }\end{array}$ & $\begin{array}{l}\text { Active } \\
\text { surveillance } \\
\text { without } \\
\text { adjuvant } \\
\text { therapy }\end{array}$ \\
\hline $\begin{array}{l}\text { Nayak } \\
\text { et al. } \\
(4)\end{array}$ & 52 & M & $\begin{array}{l}\text { Posterior } \\
\text { urethral } \\
\text { valves, ileal } \\
\text { diversion at } \\
\text { the age of } 6 \\
\text { months }\end{array}$ & Colon & 32 & $\begin{array}{l}\text { Native } \\
\text { bladder, } \\
\text { then } \\
\text { bilateral } \\
\text { pelvis } \\
\text { and } \\
\text { ureters }\end{array}$ & $\begin{array}{l}\text { Adenocarcinoma } \\
\text { and } \\
\text { Neuroendocrine } \\
\text { carcinoma }\end{array}$ & $\begin{array}{l}\text { TUR, then bilateral } \\
\text { nephrectomy, } \\
\text { ureterectomy, } \\
\text { cystoprostatectomy }\end{array}$ & $\begin{array}{c}\text { Recurrence } \\
\text { in urinary } \\
\text { tract }(+) \text {, } \\
\text { distant } \\
\text { metastasis } \\
(+), \text { alive } \\
\text { after } 3 \\
\text { months }\end{array}$ \\
\hline $\begin{array}{l}\text { Present } \\
\text { case }\end{array}$ & 76 & $\mathrm{~F}$ & $\begin{array}{l}\text { Hypersensitive } \\
\text { bladder with } \\
\text { small capacity }\end{array}$ & Ileum & 30 & Urethra & Absent & Tumor excision & $\begin{array}{l}\text { No } \\
\text { recurrence } \\
\text { after } 28 \\
\text { months }\end{array}$ \\
\hline
\end{tabular}

* Age at villous adenoma diagnosis, ECP: Enterocystoplasty.

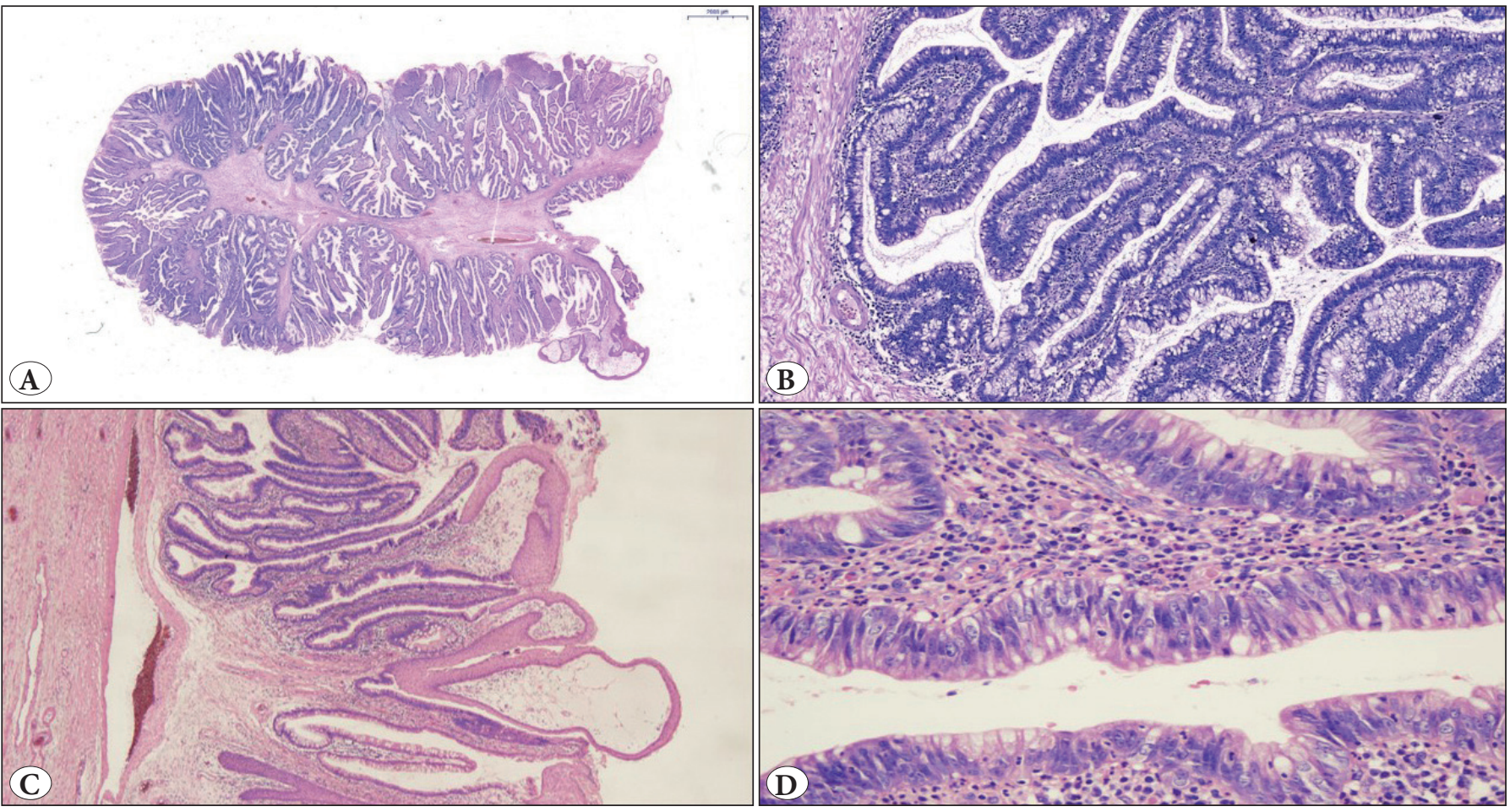

Figure 1: Microscopic view of the urethral villous adenoma. A) A slide photograph shows thin papillary structures adhering to a fibrous core (H\&E; x4). B) Villous structures covered with pseudostratified intestinal type epithelium (H\&E; x100). C) Squamous metaplasia areas (H\&E; x40). D) Low-grade dysplasia of adenomatous epithelium (H\&E; x400). 

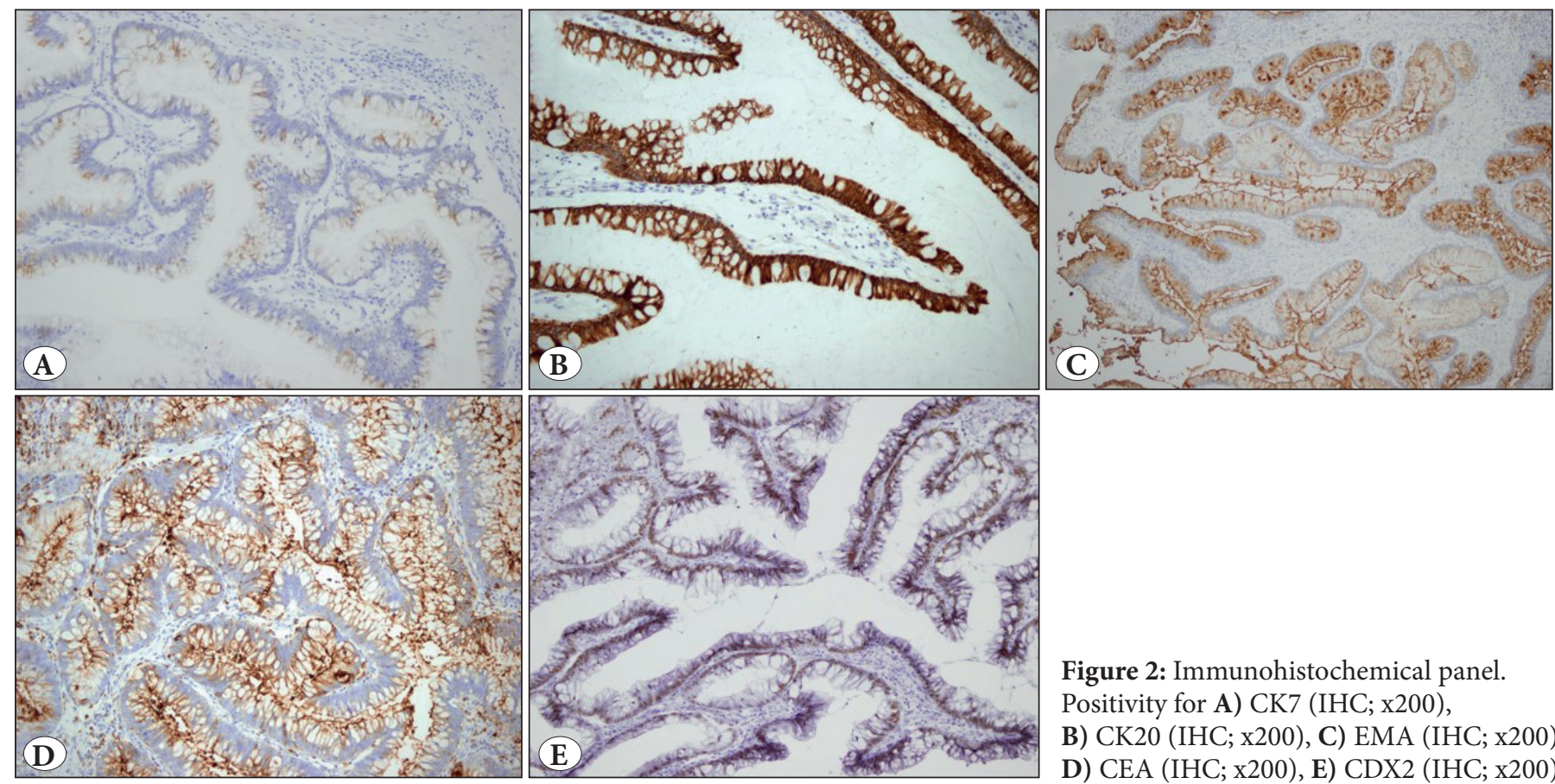

Urinary tract VAs mostly arise in the urachus, dome, or trigone of the bladder $(1,4)$. Cases located in the urethra, renal pelvis, and ureter have also been reported $(6,20-22)$. Dong et al. have reported that they found only 8 cases of pelvic VA in the English literature and presented 2 additional cases (22). Qin et al. also reported that they found only 11 cases with urethral VA between 1981 and 2003. Six of these, and the case which they presented, were female (6). Our presented case is therefore the eighth VA case arising in the female urethra, as far as we are aware.

Two possibilities have been reported in the etiology of VAs. According to the first theory, the distal colorectum, bladder and urethra originate from the cloacal tissue during embryogenesis, and these tumors may develop from the cloacal remnants. This also explains the morphological and cytogenetic similarity of the urinary tract lesions and their counterparts in the gastrointestinal system. According to the second theory, VAs are a product of the irritationmetaplasia-dysplasia-carcinoma sequence (3). Intestinal metaplasia of the urinary tract is often associated with chronic inflammation, in particular infection, stones and chemical injury (16). The presence of neutral mucins, acidic sulfomucins, and sialomucins in both cystitis glandularis and VA, and the similar genetic characteristics in the dysplastic regions of the metaplastic mucosa and VA support this theory $(3,23)$.

Augmentation cystoplasty using the colon, ileum or stomach is an accepted reconstructive option for patients with intractable incontinence and poor bladder compliance due to neurogenic and non-neurogenic disorders (6). However, it has been reported that the risk of developing bladder carcinoma increases 7-8 times with ileum and colon segments, and 14-15 times with gastric segments $(4,12)$. The most common histologic types are adenocarcinoma and urothelial carcinoma (12). The incidence of VAs after cystoplasty is very low and most of them develop in the neobladder or anastomosis line (24). To our knowledge, only 2 cases of VAs originating from the native bladder mucosa have been reported $(4,12)$. It is thought that the development of bladder VA in patients with a history of augmentation supports the irritation-metaplasia-dysplasiacarcinoma sequence theory $(4,12)$.

Our presented case had a history of intestinal augmentation cystoplasty 30 years ago. However, VA had developed in the urethral mucosa and protruded from the urethral meatus. USG revealed that there was no relation with the bladder. Our case is the first VA in a female urethra with a bladder augmentation history. This case could also be another example supporting the second theory.

Histologically, VAs consist of long villoglandular structures with a central fibrovascular core and these structures are lined by pseudostratified columnar epithelium $(1,13)$. The epithelial cells display nuclear stratification, crowding, hyperchromasia and occasional prominent nucleoli. Variable mitotic figures are seen in situ and in the invasive component (1). There is frequently a background of 
chronic cystitis and association with intestinal/squamous metaplasia, cystitis cystica and cystitis glandularis (2).

Two-thirds of the cases may have simultaneous malignant tumors such as urothelial carcinoma, and in situ or infiltrative adenocarcinoma (2). Therefore, all of the excision material should be examined carefully (2). In our case, we investigated all excision material and there was no high-grade dysplasia or in situ/invasive carcinoma focus.

Immunohistochemically, CK20 positivity was reported at a rate of $100 \%$, while CEA and EMA can be positive. CDX2 positivity is also reported (25). CK7 positivity is observed in approximately half of the cases $(1,3,26)$. Our case showed positivity for all these markers.

Distinction from tumor metastasis of adjacent organs such as colon, the female genital system, and the prostate is important. For females with genital system adenocarcinoma, Ca125, ER, PR can be helpful as diagnostic markers (6). Morphological differential diagnosis between metastatic adenocarcinoma of the gastrointestinal system and urinary tract VAs is impossible. CK7 positivity can support VAs of the urinary tract $(3,6)$. In the male urethra, morphological features of prostatic ductal adenocarcinoma can easily mimic VA (27). Expression of prostatic lineage markers such as PSA and PSMA could be helpful to differentiate the two entities (13).

Cytologically, it is difficult to distinguish VAs from other glandular lesions. However, VAs must be considered in the differential diagnosis when many glandular cells or mucinous cells without atypia are recognized in the urine (28).

Excision is curative for pure VAs. Carcinoma transformation and recurrence were not reported in pure cases during a mean follow up of 9.9 years (1). However, more aggressive treatment may be indicated for the VAs coexisting with a malignant tumor as adenocarcinoma to prevent recurrence and metastasis $(1,6)$. In VAs of yjr calyx, the adenoma may result in atypical hyperplasia and cancerization due to continuous inflammation stimulation, and surgical resection is therefore recommended (22). In the ureters, tumor growth with mucus retention may be the main cause of ureteral obstruction, and total excision of the tumor prevents early obstruction (29). In patients with bladder augmentation, long-term active surveillance is necessary in terms of neoplasia development $(12,24)$. In our presented case, the urethral tumor was excised. Although the surgical margin was microscopically positive, there was no recurrence in 28-month follow-up.
In conclusion, our case is the first VA arising in the female urethra with a history of bladder augmentation. The present case report supports the irritation-metaplasia-dysplasiacarcinoma sequence theory. Excision is curative for pure VAs. Transformation to carcinoma or recurrence has not been reported. However, there may be an accompanying malignant tumor such as adenocarcinoma, urothelial carcinoma etc. in one-third of the cases. Therefore, all excision material should be examined carefully. Routine endoscopic follow-up should be performed in cases with bladder augmentation. Further studies are needed to establish the nature of urinary tract VAs.

\section{CONFLICT of INTEREST}

The authors declare no conflict of interest.

\section{AUTHORSHIP CONTRIBUTIONS}

Concept: HD, Design: HD, NU, Data collection or processing: HD, SC, SC, Analysis or Interpretation: HD, NU, Literature search: HD, Writing: HD, Approval: NU.

\section{REFERENCES}

1. Cheng L, Montironi R, Bostwick DG. Villous adenoma of the urinary tract: A report of 23 cases, including 8 with coexistent adenocarcinoma. Am J Surg Pathol. 1999;23:764-71.

2. Seibel JL, Prasad S, Weiss RE, Bancila E, Epstein JI. Villous adenoma of the urinary tract: A lesion frequently associated with malignancy. Hum Pathol. 2002;33:236-41.

3. Fernandes G, Munde S, Rojekar A. Pure Villous Adenoma of the Vesicoureteric Junction Presenting as Pyonephrosis. J Clin Diagn Res. 2017;11:ED04-ED05.

4. Nayak A, Depasquale B, Vergara N, Guzzo TA, Lal P. Villous adenoma arising in the native bladder mucosa and the upper urinary tract with coexisting neuroendocrine carcinoma following augmentation cystoplasty. Int J Surg Pathol. 2019;27:450-6.

5. Atik E, Akansu B, Davarci M, Inci M, Yalcinkaya F, Rifaioglu M. Villous adenoma of the urinary bladder: Rare location. Contemp Oncol (Pozn). 2012;16:276-7.

6. Qin LF, Liang $\mathrm{Y}$, Xing XM, Wu H, Yang XC, Niu HT. Villous adenoma coexistent with focal well-differentiated adenocarcinoma of female urethral orifice: A case report and review of literature. World J Clin Cases. 2019;7:891-7.

7. Noel JC, Fayt I, Aguilar SF. Adenosquamous carcinoma arising in villous adenoma from female vulvar urethra. Acta Obstet Gynecol Scand. 2006;85:373-6.

8. Powell I, Cartwright H, Jano F. Villous adenoma and adenocarcinoma of female urethra. Urology. 1981;18:612-4.

9. Raju GC, Roopnarinesingh A, Woo J. Villous adenoma of female urethra. Urology. 1987;29:446-7.

10. Howells MR, Baylis MS. Benign urethral villous adenoma. Case report. Br J Obstet Gynaecol. 1985;92:1070-1. 
11. Morgan DR, Dixon MF, Harnden P. Villous adenoma of urethra associated with tubulovillous adenoma and adenocarcinoma of rectum. Histopathology. 1998;32:87-9.

12. Lin TP, Chen M, Hsu JM, Sheu JC. Adenocarcinoma arising from tubulovillous adenoma in a native bladder following gastrocystoplasty. Pediatr Surg Int. 2014;30:123-6.

13. McKenney JK. Precursor lesions of the urinary bladder. Histopathology. 2019;74:68-76.

14. Sung W, Park BD, Lee S, Chang SG. Villous adenoma of the urinary bladder. Int J Urol. 2008;15:551-3.

15. Karnjanawanichkul W, Tanthanuch M, Mitarnun W, Pripatnanont C. Renal pelvic villous adenoma presented with mucusuria: Report of a case and literature review. Int J Urol. 2013;20:247-9.

16. Hudson J, Arnason T, Merrimen JL, Lawen J. Intestinal type villous adenoma of the renal pelvis. Can Urol Assoc J. 2013;7:E138-42.

17. Pal DK. Villous adenoma of the urinary bladder. J Cancer Res Ther. 2015;11:665.

18. Kato Y, Konari S, Obara W, Sugai T, Fujioka T. Concurrence of villous adenoma and non-muscle invasive bladder cancer arising in the bladder: A case report and review of the literature. BMC Urol. 2013;13:36.

19. Tamboli P, Ro JY. Villous adenoma of urinary tract: A common tumor in an uncommon location. Adv Anat Pathol. 2000;7:79-84

20. Fernando Val-Bernal J, Torío B, Mayorga M, García-Arranz P, Garijo MF. Concurrent tubulovillous adenoma and transitional cell carcinoma associated with diffuse gastric and intestinal metaplasia of the defunctioned ureter. Pathol Res Pract. 2001;197:507-13.
21. Bhat S, Chandran V. Villous adenoma of the renal pelvis and ureter. Indian J Urol. 2010;26:598-9.

22. Dong C, Yang Y, Wu S, Chen G. Clinicopathological analysis of two cases with pelvis villous adenoma and review of relevant literature. J Cancer Res Ther. 2015;11:663.

23. Channer JL1, Williams JL, Henry L. Villous adenoma of the bladder. J Clin Pathol. 1993;46:450-2.

24. Hayashi Y, Shiyanagi S, Nagae I, Ishizaki T, Kasuya K, Katsumata K, Yamataka A, Tsuchida A. A case of tubular adenoma developing after bladder augmentation: Case report and literature review. Int J Surg Case Rep. 2016;19:17-20.

25. Wang J, Manucha V. Villous adenoma of the urinary bladder: A brief review of the literature. Arch Pathol Lab Med. 2016;140:913.

26. Nakamura Y, Orikasa K, Fujishima F, Shibahara Y, Saito R, Ohkubo T, Ueno S, Sasano H. A case of villous adenoma of the urinary bladder with tubulovillous architecture: Characterization by immunohistochemical analysis. Pol J Pathol. 2011;62:179-82.

27. Sato K, Tachibana H, Tsuzuki T, Ueda Y, Katsuda S. Prostatic ductal adenocarcinoma mimicking villous adenoma of the urethra. Virchows Arch. 2006;449:597-9.

28. Ishikawa R, Kadota K, Hayashi T, Motoyama M, Matsunaga T, Miyai Y, Katsuki N, Kushida Y, Haba R. Cytopathological features of villous adenoma of the urinary bladder in urine: A rare case report. Diagn Cytopathol. 2016;44:632-5.

29. Shih CM, Wu SC, Lee CC, Pan CC. Villous adenoma of the ureter with manifestation of mucus hydroureteronephrosis. J Chin Med Assoc. 2007;70:33-5. 